\title{
Graveyard of Clerics: Everyday Activism in Saudi Arabia. Pascal Menoret (Stanford, CA: Stanford University Press, 2020). Pp. 246. \$24.00 paper. ISBN: $9781503612464-$ Corrigendum
}

Jonas Elbousty

DOI: https://doi.org/10.1017/S0020743821000489; First published online by Cambridge University Press 06 July 2021

In the original publication of Elbousty (2021), an error occurred in the title of the book review. The correct title of the book is reproduced below:

Graveyard of Clerics: Everyday Activism in Saudi Arabia

The original publication has been updated to reflect this change.

\section{Reference}

Elbousty, J. (2021). Graveyard of Clerics: Everyday Activism in Saudi Arabia. Pascal Menoret (Stanford, CA: Stanford University Press, 2020). Pp. 246. \$24.00 paper. ISBN: 9781503612464. International Journal of Middle East Studies 53, no. 3. doi:10.1017/ S0020743821000489

Cite this article: Elbousty J (2021). Graveyard of Clerics: Everyday Activism in Saudi Arabia. Pascal Menoret (Stanford, CA: Stanford University Press, 2020). Pp. 246. \$24.00 paper. ISBN: 9781503612464 - Corrigendum. International Journal of Middle East Studies 53, 567. https://doi.org/10.1017/S0020743821000854

(C) The Author(s), 2021. Published by Cambridge University Press 